\title{
Efficacy of opioids versus placebo in chronic pain: a systematic review and meta-analysis of enriched enrollment randomized withdrawal trials
}

This article was published in the following Dove Press journal: Journal of Pain Research

\author{
Diana S Meske' \\ Oluwadolapo D Lawal' \\ Harrison Elder' \\ Valerie Langberg ${ }^{2}$ \\ Florence Paillard' \\ Nathaniel Katz ${ }^{1,3}$ \\ 'Analgesic Solutions, Natick, MA, \\ USA, ${ }^{2}$ The Center for Evidence \\ Synthesis in Health, Brown University, \\ Providence, RI, USA, ${ }^{3}$ Department \\ of Anesthesiology and Perioperative \\ Medicine, Tufts University School of \\ Medicine, Boston, MA, USA
}

\begin{abstract}
Introduction: Opioids have been used for millennia for the treatment of pain. However, the long-term efficacy of opioids to treat chronic non-cancer pain continues to be debated. To evaluate opioids' efficacy in chronic non-cancer pain, we performed a meta-analysis of published clinical trials for $\mu$-opioid receptor agonists performed for US Food and Drug Administration approval. Methods: MEDLINE and Cochrane trial register were searched for enriched enrollment randomized withdrawal studies (before June 2016). Selection criteria included: adults, $\geq 10$ subjects per arm, any chronic pain condition, double-blind treatment period lasting $\geq 12$ weeks, and all $\mu$-agonist opioids approved in the USA.
\end{abstract}

Results: Fifteen studies met criteria. Opioid efficacy was statistically significant $(p<0.001)$ versus placebo for pain intensity (standardized mean difference: -0.416 ), $\geq 30 \%$ and $\geq 50 \%$ improvement in pain (risk difference: 0.166 and 0.137), patient global impression of change (0.163), and patient global assessment of study medication (0.194). There were minor benefits on physical function and no effect on mental function.

Conclusion: Opioids are efficacious in the treatment of chronic non-cancer pain for up to 3 months in randomized controlled trials. This should be considered, alongside data on opioid safety, in the use of opioids for the treatment of chronic pain.

Keywords: opioid analgesics, non-cancer pain, long-term efficacy, EERW trials, opioid efficacy; evidence-based medicine

\section{Introduction}

Opioids have been used for millennia for the treatment of pain and remain an important therapeutic option. While the American Academy of Pain Medicine, the American Pain Society, the US Federation of State Medical Boards, and the Centers for Disease Control and Prevention endorse the use of opioids, when appropriate, for the treatment of chronic pain, efficacy of long-term opioid use remains controversial. ${ }^{1-6}$ In addition, there are significant risks associated with opioids and these agents have contributed to the epidemic of opioid abuse, addiction, and overdose deaths in the USA. ${ }^{7-10}$ Given these serious risks, the assessment of evidence for the long-term analgesic efficacy of opioids for treating chronic pain is crucial.

The US Food and Drug Administration (FDA) requires randomized, double-blind, placebo-controlled studies of at least 3 months' duration in order to approve an opioid for the treatment of chronic pain. This reflects the need to balance accrual of sufficient data representative of long-term treatment against the scientific and ethical challenges of longer-term randomized, placebo-controlled trials, including dropouts, missing data, concomitant treatments, and long-term use of placebo. The 3-month duration is
Correspondence: Nathaniel Katz Analgesic Solutions, 232 Pond Street, Natick, MA 01760, USA

Tel +l 78I 4449605

Email nkatz@analgesicsolutions.com 
the standard clinical trial duration accepted by the FDA for many chronic conditions including hypertension, asthma, depression, schizophrenia, bipolar disorder, and anxiety.

In order to inform the ongoing controversy over whether there is evidence that opioids are efficacious for the treatment of chronic pain, we have gathered the randomized controlled trials required by the FDA for approval, and have performed a meta-analysis of their results. These trials are by regulatory expectation 3 months in duration. This review does not address the risks of opioids. A coherent position on the risk-benefit balance of opioids for the treatment of chronic pain requires an accurate and data-driven assessment of both their risks and their benefits. Thus, the purpose of this review is not to minimize, or characterize, the risks of opioids, but rather to ensure that the debate over the risks and benefits of opioids is informed by an accurate assessment of their benefits.

\section{Methods}

\section{Data sources and searches}

MEDLINE and Cochrane Central Register of Controlled Trials 2012 were searched for all relevant studies published before June 2016. The search strategy for MEDLINE is presented (see Methods in Supplementary materials) and was customized for the Cochrane Central Register of Controlled Trials 2012 (in which only the Intervention and Population sections were used). Additional studies were identified through the examination of references from identified trials, systematic reviews, and authors' own databases.

We searched for enriched enrollment randomized withdrawal (EERW) studies published in English with doubleblinded outcome assessments that compared any opioid (including combinations and dual mechanism analgesics administered via the oral, transdermal, nasal, sublingual, or transmucosal routes) to placebo for $\geq 12$ weeks during the randomized double-blind treatment phase of the study in patients with any chronic non-malignant pain condition.

\section{Study selection}

\section{Inclusion and exclusion criteria}

Trials with participants $\geq 18$ years of age with any type of chronic nonmalignant pain, including but not limited to chronic low back pain (CLBP), chronic neuropathic pain, diabetic peripheral neuropathic pain (DPNP), osteoarthritis (OA), arthritis, rheumatoid arthritis, phantom limb pain, fibromyalgia, post-herpetic neuralgia, or musculoskeletal pain. Studies of acute or post-surgical pain and cancer pain were excluded. Studies of specific $\mu$-agonist opioids, $\mu$-agonist opioids with additional pharmacological activity (eg, tramadol and tapentadol), or combination opioids (eg, hydrocodone/acetaminophen) approved for the treatment of pain were included. Agents with oral, transdermal, nasal, sublingual, or transmucosal routes of administration were included. Studies were included if they had a minimum of 10 patients per arm and reported pain intensity (PI) as an outcome. The present study protocol has been published on PROSPERO (http://www.crd.york.ac.uk/PROSPERO/; registration No: CRD42015026378).

\section{Selection methodology}

Two authors independently screened titles and abstracts using the Abstrackr software to identify manuscripts that met the abovementioned inclusion criteria. ${ }^{11}$ Full-text articles were obtained for manuscripts that appeared to meet the inclusion criteria or were likely to meet the inclusion criteria. The full text of these manuscripts was read to determine final inclusion in the meta-analysis. Any disagreement on manuscript inclusion was resolved through discussion among the authors.

\section{Data extraction and quality assessment Data extraction methodology}

Two authors independently extracted data from each manuscript using the Systematic Review Data Repository (SRDR) form (http://srdr.ahrq.gov/; retrieved: June 1 2016). A third author subsequently confirmed that primary and secondary endpoints matched the SRDR form. The SRDR is an open collaborative web-based repository for systematic data review. The SRDR form was developed to include participant characteristics, interventions, treatment arms, adverse events (AEs), primary and secondary outcomes, country(s) of study, number of study sites, trial design, blinding, clinical setting, method of recruitment, group similarities at baseline, and assessment bias. If data were not available or incomplete, manuscript authors were contacted to provide the missing data.

\section{Quality assessment}

Risk of bias was assessed based on the guidelines available through the Cochrane Risk of Bias Tool of the SRDR (http://handbook.cochrane.org/chapter 8/table 85 a the cochrane collaborations tool for assessi ng.htm). We defined high-quality studies (ie, low bias studies) as those with no major methodological flaws that fulfilled 6 or more of the 11 internal validity criteria. ${ }^{12}$

\section{Data extracted}

The following outcome measures were extracted from the selected publications: change in PI score from randomization 
baseline to week 12 or study endpoint, categorical evaluation of responders/non-responders ( $\geq 30 \%$ and $\geq 50 \%$ improvement as calculated based on changes between week 12 and pain at the beginning of the open-label titration phase), patient assessments of global improvement (eg, patient global impression of pain [PGIC] and patient global assessment of study medication [PGASM]), assessment of patient change in function (eg, Roland-Morris Disability Questionnaire [RMDQ] and Western Ontario and McMaster Universities Arthritis Index [WOMAC]), rescue medication dose consumption, and health-related quality of life (eg, 36-Item Short-Form Survey [SF-36]).

Safety outcomes collected included: the proportion of patients with $\geq 1 \mathrm{AE}, \geq 1$ serious $\mathrm{AE}$ (SAE), discontinuing treatment due to AEs and/or withdrawal symptoms postrandomization; AEs during the open-label titration phase were not collected.

\section{Data synthesis and analysis}

The primary outcome was standardized effect size, defined as the treatment difference (mean difference in PI score between active and placebo) divided by the SD. We pooled data from all manuscripts regardless of whether the endpoint was presented as mean change from randomization baseline to week 12 or as the least squares mean difference (LSMD) at week 12; if both results were available, the mean change from randomization baseline to week 12 was used. The mean change from baseline was calculated from the reported mean baseline and week 12 data; the SD of the change was calculated by assuming a correlation of 0.50 between baseline and week 12 responses. The standard mean difference (SMD) was calculated with $95 \%$ CIs. The change in PI from randomization baseline to week 12 was reported as the LSMD and standard error (SE); in case SD or SE were not available, they were calculated based on the following formula: $\mathrm{SE}=$ $\mathrm{SD}$ /square $\operatorname{root}(\mathrm{N})$. When $\mathrm{SD}$ values were not available, the manuscript authors were contacted. We were able to obtain all unpublished SD values. The number of subjects randomized was used in all analyses except in situations where a different $\mathrm{N}$ value was more appropriate to use (eg, some manuscripts did not present data for $100 \%$ of patients in PGIC tables; in this situation, we calculated the total number of patients randomized based on the percentage of reporting patients).

A binary random-effects meta-analysis using the restricted maximum likelihood method was conducted to assess $\geq 30 \%$ and $\geq 50 \%$ responder rates. The results are reported as risk differences (RDs). The same approach was used for PGIC results (combining "very much improved" and "much improved" responses) and PGASM (combining "excellent" and "very good" results). Function endpoints were not reported in all manuscripts, and for manuscripts that did report function endpoints, a variety of different measures were used (RMDQ, WOMAC, and Oswestry Disability Index). Therefore, no meta-analysis was performed; instead, these data were presented in a tabular format. Quality of life measures (mean change from baseline to week 12; SF-36 or SF-12v2) were combined and a meta-analysis was conducted using a linear regression model. The numbers of patients who discontinued treatment due to an AE were subjected to a binary randomeffects meta-analysis using the restricted maximum likelihood method. The results are presented as RDs. In order to assess the percent of patients who benefited from the study drug, a weighted mean was calculated for the percentage of patients who met inclusion criteria (ie, found the study drug both efficacious and tolerable) and were randomized to the randomized double-blind treatment phase. The statistical analysis was performed using the OpenMetaAnalyst Software. ${ }^{13}$

\section{Meta-analysis findings}

A total of 2,018 references were identified from our search; of these, 26 full-text articles were obtained for screening and 15 met our inclusion criteria (Figure 1). ${ }^{14-28}$

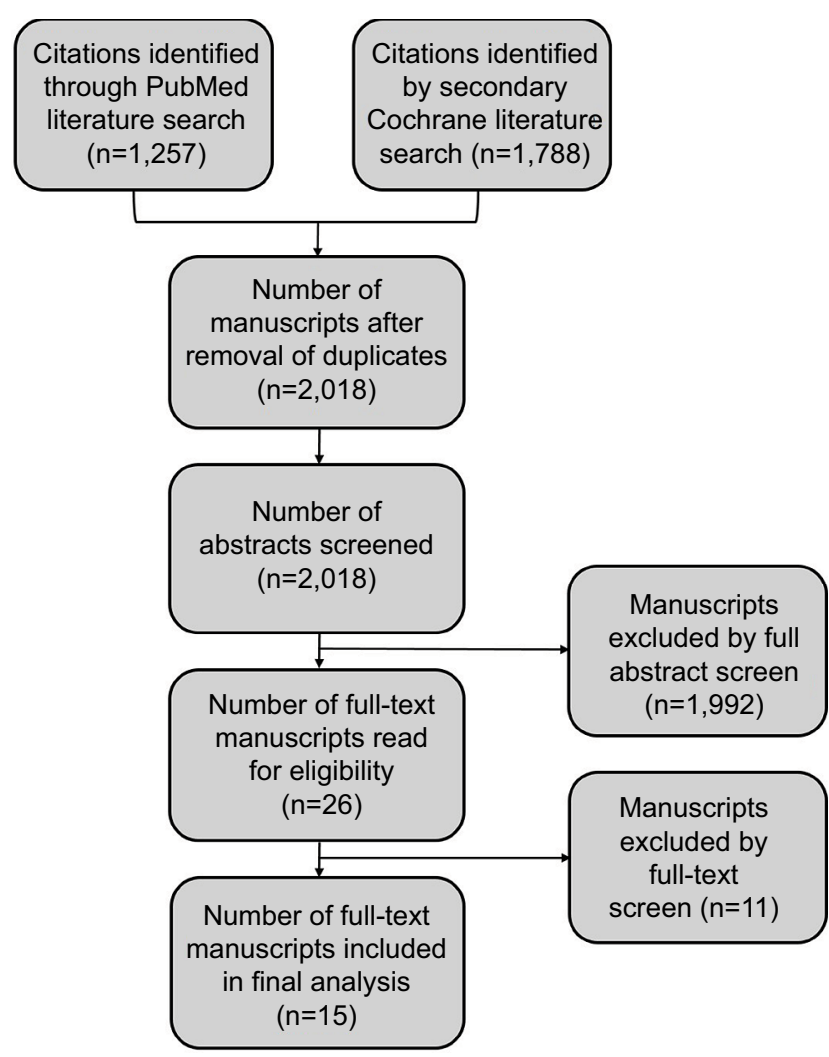

Figure I Study flow diagram. 


\section{Included studies}

A summary of the characteristics of EERW trials included in the meta-analysis is presented in Table 1 and Table S1. Fourteen of the 15 studies were considered high-quality studies (having low bias; Table S2). Hydrocodone was evaluated in 4 trials; oxymorphone, oxycodone, buprenorphine and tapentadol in 2 trials each; and hydromorphone, morphine/ naltrexone, and tramadol in 1 trial each. CLBP was evaluated in 10 studies, DPNP in 2 studies, OA in 2 studies, and 1 study evaluated a combination of CLBP and OA patients.

\section{Study design}

All included studies were randomized, double-blind, placebocontrolled EERW studies as defined by the literature search inclusion criteria. All included studies used a parallel group design during the randomized double-blind treatment phase. In 13 of the 15 trials, patients were initially titrated to an individualized effective dose and then either allowed to continue their individualized dose or randomized to the placebo group during the randomized double-blind treatment phase. In 1 trial, ${ }^{14}$ all patients were titrated to the highest dose of the study drug and subsequently randomized to a high-dose group, a low-dose group, or the placebo group. In another trial, ${ }^{15}$ all patients were allowed to adjust the titrated dose after randomization for the first 4 weeks and then the dose was fixed for the next 8 weeks.

The open-label titration phase lasted between 2 and 8 weeks and the randomized double-blind treatment phase lasted 12 weeks for all studies (Table 1). Most studies made

Table I Study design and subject disposition by study

\begin{tabular}{|c|c|c|c|c|c|c|}
\hline Author, year & Drug, pain type & $\begin{array}{l}\text { No of sites, } \\
\text { Countries }\end{array}$ & $\begin{array}{l}\text { Opioid naive } \\
\text { patients, n (\%) }\end{array}$ & $\begin{array}{l}\text { Patients } \\
\text { enrolled in } \\
\text { the OLP, } n\end{array}$ & $\begin{array}{l}\text { Discontinued } \\
\text { during OLP, \% }\end{array}$ & $\begin{array}{l}\text { OLP } \\
\text { duration }\end{array}$ \\
\hline Hale et al, ${ }^{14} 2007$ & Oxymorphone ER, CLBP & 30, USA & $0(0)$ & 251 & 43 & $\begin{array}{l}\text { Up to I } \\
\text { month }\end{array}$ \\
\hline Katz et al, ${ }^{9} 2007$ & Oxymorphone ER, CLBP & 29, USA & $205(100)$ & 326 & 37 & $\begin{array}{l}\text { Up to I } \\
\text { month }\end{array}$ \\
\hline Vorsanger et al, ${ }^{20} 2008$ & Tramadol ER, CLBP & 30, USA & Not stated & 619 & 38 & 3 weeks \\
\hline Hale et al, ${ }^{21} 2010$ & $\begin{array}{l}\text { OROS Hydromorphone ER, } \\
\text { CLBP }\end{array}$ & 66, USA & $0(0)$ & 459 & 42 & $\begin{array}{l}\text { Up to I } \\
\text { month }\end{array}$ \\
\hline Katz et al, ${ }^{22} 2010$ & $\begin{array}{l}\text { EMBEDA }^{\circledR} ; \text { MS-sNT (morphine } \\
\text { sulfate and naltrexone } \\
\text { hydrochloride ER capsules), OA }\end{array}$ & $\begin{array}{l}\text { Not stated, } \\
\text { USA }\end{array}$ & $254(73.8)$ & 547 & 37 & Up to 45 days \\
\hline Schwartz et al, ${ }^{23} 201 \mathrm{I}$ & Tapentadol ER, DPNP & $\begin{array}{l}\text { 93, USA and } \\
\text { Canada }\end{array}$ & $255(65.5)$ & 588 & 33 & 3 weeks \\
\hline Friedmann et al, ${ }^{15} 201 \mathrm{l}$ & Remoxy (Oxycodone ER), OA & 61, USA & Not stated & 558 & 26 & 2 weeks \\
\hline Steiner et al, ${ }^{16} 201 \mathrm{l}$ & $\begin{array}{l}\text { Buprenorphine transdermal } \\
\text { system (BTDS), CLBP }\end{array}$ & 86, USA & $54 I(100)$ & 1024 & 47 & Up to 27 days \\
\hline Rauck et al, ${ }^{24} 2014$ & $\begin{array}{l}\text { Zohydro (Hydrocodone ER), } \\
\text { CLBP }\end{array}$ & 59, USA & $0(0)$ & 510 & 41 & $\begin{array}{l}\text { Up to } 6 \\
\text { weeks }\end{array}$ \\
\hline Vinik et al, ${ }^{25} 2014$ & Tapentadol ER, DPNP & $\begin{array}{l}80, \text { USA and } \\
\text { Canada }\end{array}$ & $218(68.5)$ & 459 & 22 & 3 weeks \\
\hline Wen et al, ${ }^{17} 2015$ & $\begin{array}{l}\text { Hysingla ER (Hydrocodone } \\
\text { bitartrate ER), CLBP }\end{array}$ & 102, USA & $329(56)$ & 905 & 35 & Up to 45 days \\
\hline Katz et al, ${ }^{18} 2015$ & $\begin{array}{l}\text { Xtampa ER (Oxycodone ER), } \\
\text { CLBP }\end{array}$ & 46, USA & $192(49.3)$ & 740 & 47 & $\begin{array}{l}\text { Up to } 6 \\
\text { weeks }\end{array}$ \\
\hline Hale et al, $^{26} 2015$ & Hydrocodone ER, CLBP/OA & 71, USA & $147(50)$ & 389 & 24 & $\begin{array}{l}\text { Up to } 6 \\
\text { weeks }\end{array}$ \\
\hline Hale et al, ${ }^{27} 2015$ & Hydrocodone ER, CLBP & 78, USA & $215(58)$ & 625 & 41 & $\begin{array}{l}\text { Up to } 6 \\
\text { weeks }\end{array}$ \\
\hline Rauck et al, ${ }^{28} 2016$ & Buccal buprenorphine, CLBP & 60, USA & $420(100)$ & 749 & 39 & $\begin{array}{l}\text { Up to } 8 \\
\text { weeks }\end{array}$ \\
\hline
\end{tabular}

Notes: ${ }^{a}$ Number of sites initiated. ${ }^{b}$ Concomitant analgesics were not allowed during the dosed titration. The paper does not state anything about concomitant analgesics for the period following this.

Abbreviations: CLBP, chronic low back pain; DPNP, diabetic peripheral neuropathic pain; ER, extended release; OA, osteoarthritis; OLP, open label phase; RBTP, randomized blinded treatment phase. 
efforts to prevent or reduce discontinuation of patients randomized to the placebo group in the randomized double-blind treatment phase by allowing the use of rescue medication $(12 / 15)$ and/or tapering the opioid in placebo patients $(10 / 15$; Table 1). All studies analyzed the intent-to-treat population for primary and secondary outcomes.

\section{Efficacy}

\section{Primary endpoint: PI}

With regard to primary endpoint measurements, the change from randomization baseline to week 12 was reported by 4 studies as the LSMD, ${ }^{14,16-18}$ and by all other studies as the mean change (Table S1) ${ }^{15,19-28}$ The effect of opioids was statistically significant $(p<0.001)$ versus placebo for the change in PI score from randomization baseline to week 12 (SMD $=-0.416$; 95\% CI: -0.521 to -0.312 ; Figure 2 ) as assessed by binary random-effects model meta-analysis using the restricted maximum likelihood method. Only 1 study ${ }^{15}$ did not report a statistically significant difference versus placebo for the mean change in PI from randomization baseline to week 12 (Figure 2); however, the change in area under the curve between study drug and placebo, which was the study's primary endpoint, was statistically significant.

\section{Other efficacy endpoints}

Responder rates were reported in 12 manuscripts (Tables S3 and $\underline{\mathrm{S} 4}) \cdot{ }^{16-19,22-28}$ However, 2 were excluded since they reported respondent analysis as increment in pain from baseline of the

\begin{tabular}{|c|c|c|c|c|c|}
\hline $\begin{array}{l}\text { Duration of study } \\
\text { drug tapering }\end{array}$ & $\begin{array}{l}\text { Patients randomized } \\
\text { in each arm of RBTP, } n\end{array}$ & $\begin{array}{l}\text { RBTP dosing regimen } \\
\text { and duration }\end{array}$ & $\begin{array}{l}\text { Post-randomization } \\
\text { discontinuations, \% }\end{array}$ & $\begin{array}{l}\text { Concomitant } \\
\text { analgesics } \\
\text { allowed? }\end{array}$ & $\begin{array}{l}\text { Rescue } \\
\text { medication } \\
\text { allowed? }\end{array}$ \\
\hline $\begin{array}{l}\text { No taper (4-day extended } \\
\text { access to rescue opioid) }\end{array}$ & $\begin{array}{l}\text { Oxymorphone ER: } 70 \\
\text { Placebo: } 72\end{array}$ & Fixed dose 12 weeks & $\begin{array}{l}\text { Oxymorphone ER: } 30 \\
\text { Placebo: } 76\end{array}$ & No & Yes \\
\hline $\begin{array}{l}\text { No taper (4-day extended } \\
\text { access to rescue opioid) }\end{array}$ & $\begin{array}{l}\text { Oxymorphone ER: } 105 \\
\text { Placebo: } 100\end{array}$ & Fixed dose 12 weeks & $\begin{array}{l}\text { Oxymorphone ER: } 32 \\
\text { Placebo: } 53\end{array}$ & $\mathrm{No}^{\mathrm{b}}$ & Yes \\
\hline Not stated & $\begin{array}{l}\text { Tramadol ER } 300 \mathrm{mg}: 127 \\
\text { Placebo: } 126\end{array}$ & Adjustable dose 12 weeks & $\begin{array}{l}\text { Tramadol ER } 300 \text { mg: } \\
33 \text { Placebo: } 48\end{array}$ & No & Not stated \\
\hline 2 weeks & $\begin{array}{l}\text { Hydromorphone ER: } 133 \\
\text { Placebo: } 133\end{array}$ & Fixed dose 12 weeks & $\begin{array}{l}\text { Hydromorphone ER: } 51 \\
\text { Placebo: } 68\end{array}$ & No & Yes \\
\hline 2 weeks & $\begin{array}{l}\text { MS-sNT: } 170 \\
\text { Placebo: } 173\end{array}$ & Fixed dose 12 weeks & $\begin{array}{l}\text { MS-sNT: } 36 \\
\text { Placebo: } 43\end{array}$ & No & Yes \\
\hline 3 days & $\begin{array}{l}\text { Tapentadol ER: } 196 \\
\text { Placebo: } 193\end{array}$ & Fixed dose 12 weeks & $\begin{array}{l}\text { Tapentadol ER: } 32 \\
\text { Placebo: } 32\end{array}$ & No & No \\
\hline Up to 15 days & $\begin{array}{l}\text { Oxycodone ER: } 203 \\
\text { Placebo: } 207\end{array}$ & $\begin{array}{l}\text { Adjustable for first } 4 \\
\text { weeks then fixed for } 8 \\
\text { weeks } \\
\text { Fixed dose } 12 \text { weeks }\end{array}$ & $\begin{array}{l}\text { Oxycodone ER: } 34 \\
\text { Placebo: } 36\end{array}$ & No & Not stated \\
\hline No taper & $\begin{array}{l}\text { BTDS: } 257 \\
\text { Placebo: } 283\end{array}$ & Fixed dose 12 weeks & $\begin{array}{l}\text { BTDS: } 33 \\
\text { Placebo: } 30\end{array}$ & No & Yes \\
\hline 2 weeks & $\begin{array}{l}\text { Hydrocodone ER: } 15 \mid \\
\text { Placebo: I5I }\end{array}$ & Fixed dose 12 weeks & $\begin{array}{l}\text { Hydrocodone ER: } 18 \\
\text { Placebo: } 61\end{array}$ & No & Yes \\
\hline 3 days & $\begin{array}{l}\text { Tapentadol ER: } 166 \\
\text { Placebo: } 152\end{array}$ & Fixed dose 12 weeks & $\begin{array}{l}\text { Tapentadol ER: } 28 \\
\text { Placebo: } 30\end{array}$ & No & Yes \\
\hline 2 weeks & $\begin{array}{l}\text { Hydrocodone ER: } 296 \\
\text { Placebo: } 292\end{array}$ & Fixed dose 12 weeks & $\begin{array}{l}\text { Hydrocodone ER: } 23 \\
\text { Placebo: } 28\end{array}$ & No & Yes \\
\hline Up to 20 days & $\begin{array}{l}\text { Xtampa ER: } 193 \\
\text { Placebo: } 196\end{array}$ & Fixed dose 12 weeks & $\begin{array}{l}\text { Xtampa ER: } 37 \\
\text { Placebo: } 49\end{array}$ & No & Yes \\
\hline 2 weeks & $\begin{array}{l}\text { Hydrocodone ER: I } 46 \\
\text { Placebo: I } 47\end{array}$ & Fixed dose 12 weeks & $\begin{array}{l}\text { Hydrocodone ER: } 36 \\
\text { Placebo: } 31\end{array}$ & Yes & Yes \\
\hline 2 weeks & $\begin{array}{l}\text { Hydrocodone ER: } 191 \\
\text { Placebo: } 180\end{array}$ & Fixed dose 12 weeks & $\begin{array}{l}\text { Hydrocodone ER: } 18 \\
\text { Placebo: } 21\end{array}$ & Not stated & Yes \\
\hline No taper & $\begin{array}{l}\text { Buccal Buprenorphine: } 209 \\
\text { Placebo: } 21 \text { I }\end{array}$ & Fixed dose 12 weeks & $\begin{array}{l}\text { Buccal Buprenorphine: } 24 \\
\text { Placebo: } 25\end{array}$ & No & Yes \\
\hline
\end{tabular}


Studies

Hale et al, ${ }^{14} 2007$

Katz et al, ${ }^{9} 2007$

Vorsanger et al, ${ }^{20} 2008$

Hale et al, ${ }^{21} 2010$

Katz et al, ${ }^{22} 2010$

Schwartz et al, ${ }^{23} 2011$

Friedman et al, ${ }^{15} 2011$

Steiner et al, ${ }^{16} 2011$

Rauck et al, ${ }^{24} 2014$

Vinik et al, ${ }^{25} 2014$

Wen et al, ${ }^{17} 2015$

Katz et al, ${ }^{18} 2015$

Hale et al, ${ }^{26} 2015 a$

Hale et al, ${ }^{27} 2015 \mathrm{~b}$

Rauck et al, ${ }^{28} 2016$

Overall $\left(I^{2}=72.09 \%, P<0.001\right)$
Estimate

(95\% Cl)

$-0.913 \quad(-1.259$ to -0.567$)$

$-0.574 \quad(-0.853$ to -0.294$)$

$-0.276 \quad(-0.490$ to -0.062$)$

$-0.799 \quad(-1.049$ to -0.550$)$

$-0.249 \quad(-0.462$ to -0.037$)$

$-0.672 \quad(-0.877$ to -0.468$)$

$-0.173 \quad$ (-0.367 to 0.021$)$

$-0.225 \quad(-0.395$ to -0.056$)$

$-0.308 \quad$ (-0.535 to -0.081$)$

$-0.462 \quad(-0.685$ to -0.240$)$

$-0.267 \quad(-0.429$ to -0.104$)$

$-0.592 \quad$ (-0.795 to -0.389$)$

$-0.347 \quad(-0.578$ to -0.117$)$

$-0.319 \quad(-0.524$ to -0.114$)$

$-0.333 \quad(-0.526$ to -0.141$)$

$-0.416 \quad(-0.521$ to -0.312$)$

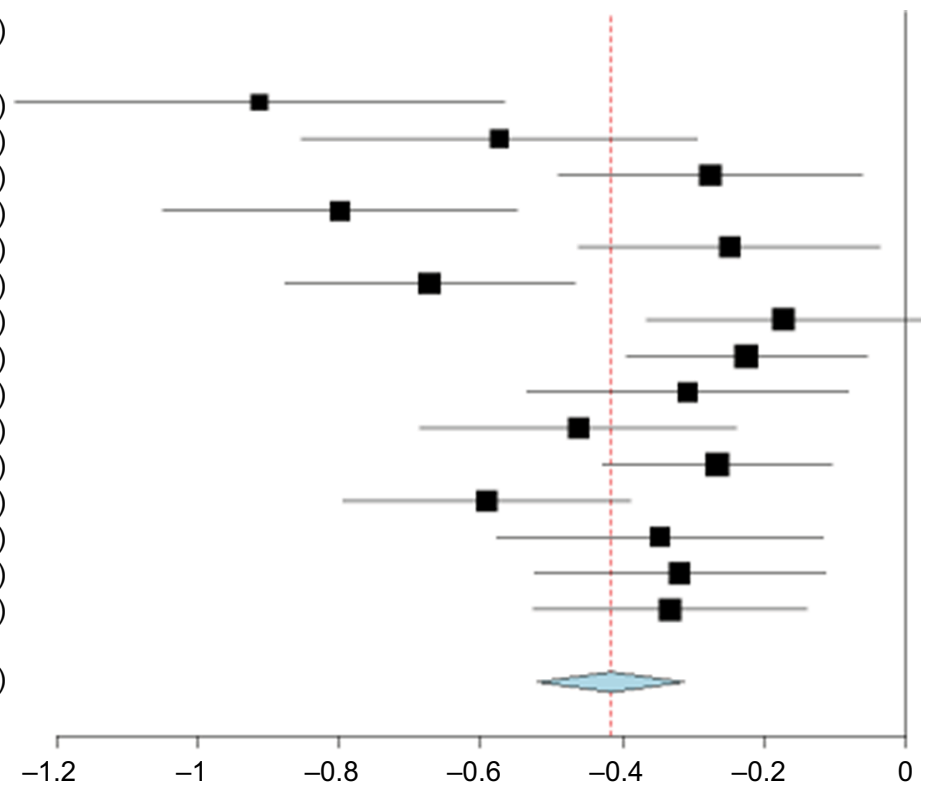

Standardized mean difference

Figure 2 Change in PI from randomization baseline to week 12 with active study opioid drug versus placebo.

Notes: The standardized mean difference effect size was -0.416 and $p<0.001$, with a lower bound estimate of -0.521 and an upper bound -0.312 .

Abbreviation: PI, pain intensity.

blinded period rather than reduction in pain from the baseline at the beginning of the open-label titration phase. ${ }^{26,27} \mathrm{~A}$ binary random-effects meta-analysis using the restricted maximum likelihood method demonstrated a statistically significant difference between study drug and placebo for both $\geq 30 \%$ (RD estimate [SE]: 0.166 [0.028], $p<0.001)$ and $\geq 50 \%(0.137$ [0.022], $p<0.001$ ) decrease from baseline in PI (Table 2; Figure 3). PGIC was reported in 5 manuscripts ${ }^{16-18,23,25}$ (Tables $\mathrm{S} 3$ and $\underline{\mathrm{S}}$ ) and meta-analysis combining patients "very much improved" and "much improved" showed a statistically significant difference between study drug and placebo in PGIC (RD estimate [SE]: 0.163 [0.029], $p<0.001$; Table 2). PGASM

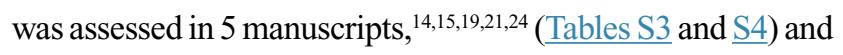
meta-analysis combining "excellent" and "very good" response showed a statistically significant difference between study drug and placebo (RD estimate [SE]: 0.194 [0.056], $p<0.001$; Table 2). Functional outcomes were reported in 5 manuscripts (Tables S3 and $\underline{\mathrm{S} 4}$ ); ${ }^{18,22,25,27,28}$ however, a variety of assessment types were reported. Three manuscripts ${ }^{18,27,28}$ reported RMDQ (mean [SD] change from baseline to week 12; study drug vs placebo: 0.4 [4.83] vs 0.7 [5.32], -1.29 [4.98] vs -1.57 [4.82], and 0.6 [5.37] vs 1.2 [5.72]), 1 manuscript ${ }^{22}$ reported WOMAC (study drug vs placebo: 1.6 [18.0] vs 5.8 [16.8]), and 1 manuscript $\mathrm{t}^{25}$ reported functional outcomes on the Brief Pain Inventory (BPI) scale (study drug vs placebo: -3.0 [2.07] vs -2.6 [2.38]) (Table S3). Due to a low number of manuscripts reporting functional outcome data and the different outcome
Table 2 Summary of secondary endpoints

\begin{tabular}{lll}
\hline Secondary endpoint & $\begin{array}{l}\text { Study drug vs } \\
\text { placebo }^{\mathbf{a}}\end{array}$ & p-value \\
\hline Responder rate for $\geq 30 \%$ improvement & $0.166(0.028)$ & $<0.00 \mathrm{I}$ \\
Responder rate for $\geq 50 \%$ improvement & $0.137(0.022)$ & $<0.00 \mathrm{I}$ \\
PGIC ("Very much improved" and & $0.163(0.029)$ & $<0.00 \mathrm{I}$ \\
"Improved") & & \\
PGASM ("Excellent" and "Very good") & $0.194(0.056)$ & $<0.00 \mathrm{I}$ \\
Patients discontinued due to an AE & $0.021(0.008)$ & $0.01 \mathrm{I}$ \\
\hline
\end{tabular}

Note: ${ }^{2}$ alues are the risk difference (RD) estimates (SE).

Abbreviations: AE, adverse event; PGASM, patient global assessment of study medication; PGIC, patient global impression of pain; SE, standard error.

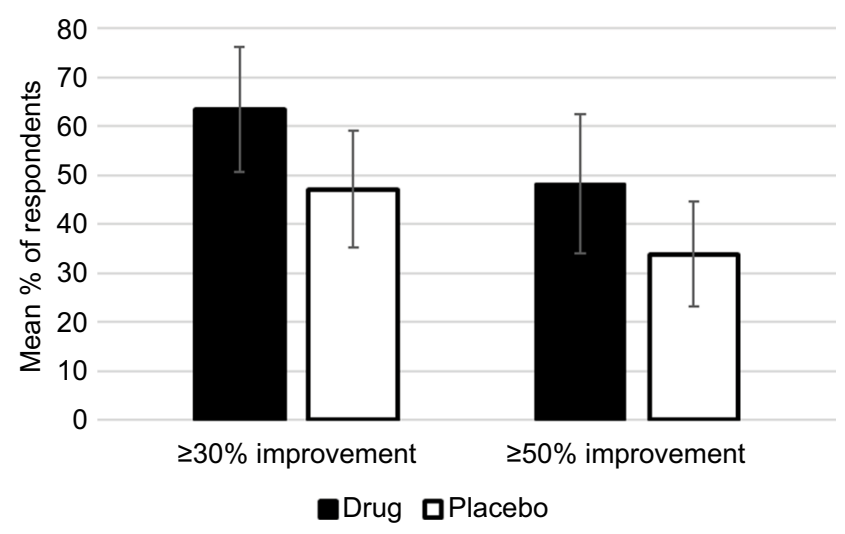

Figure 3 Percentage of patients with $\geq 30 \%$ or $\geq 50 \%$ improvement with active study drug versus placebo.

Notes: The graph shows the mean (SD) percent of patients with improvement, from each study that reported these data. A binary random-effects meta-analysis using the restricted maximum likelihood method was performed showing a statistically significant difference between active study drug and placebo for both $\geq 30 \%$ and $\geq 50 \%$. 
measure used, no meta-analysis was performed. Of these 5 manuscripts reporting functional data, 2 showed a greater improvement in function in the study drug group compared to placebo. ${ }^{22,25}$ Quality of life data were reported in only 3 manuscripts $^{16,18,25}$ (Tables S3 and $\underline{\mathrm{S} 4}$ ); therefore, no meta-analysis was performed. Physical component summary values were greater for study drug than for placebo in all 3 manuscripts ( 10.11 vs $6.12,0.1$ vs -2.3 , and 7.52 vs 3.62 ), while mental component summary values were greater for study drug versus placebo for 2 manuscripts ${ }^{16,25}$ ( 7.19 vs 3.34 and 0.20 vs -0.8 ; Table S3). No meta-analysis of rescue medication dose consumption was conducted due to insufficient data. The overall weighted mean (SD) of the percentage of patients who were randomized from the open-label titration phase was $63.2 \%$ (7.4). Data are presented for each manuscript in Table 1.

\section{Safety endpoints}

Reported AEs and SAEs post-randomization were similar between study drug and placebo in all studies (Table 3 ). The overall weighted mean discontinuation rate was numerically higher for placebo $(42.1 \%)$ than study drug $(31.0 \%)$, and was likely related to discontinuation due to lack of efficacy in the placebo group. There was a small but statistically significant difference in the percentage of patients who discontinued due to an $\mathrm{AE}$ in the study drug group versus the placebo group (RD estimate [SE]: 0.021 [0.008], $p=0.011)$. The proportion of patients who discontinued due to SAEs was not included in this analysis because no manuscript reported it. The average rate of discontinuation due to opioid withdrawal was similar between study drug and placebo (Table 3 ).

Table 3 Summary of AEs

\begin{tabular}{|c|c|c|c|c|c|}
\hline Reference & $\begin{array}{l}\text { Study drug/ } \\
\text { placebo }\end{array}$ & $\begin{array}{l}\text { Patients with } \\
\geq \text { I AE, n (\%) }\end{array}$ & $\begin{array}{l}\text { Patients with } \\
\geq \text { I SAE, n (\%) }\end{array}$ & $\begin{array}{l}\text { Patients who } \\
\text { discontinued due } \\
\text { to an AE, } n(\%)\end{array}$ & $\begin{array}{l}\text { Patients who discontinued } \\
\text { due to opioid withdrawal, } \\
\text { n (\%) }\end{array}$ \\
\hline \multirow[t]{2}{*}{ Hale et al, ${ }^{14} 2007$} & Study drug: & $31(44.3)$ & $2(2.9)$ & $7(10.0)$ & $0(0.0)$ \\
\hline & Placebo: & $27(37.5)$ & $0(0.0)$ & $8(I I . I)$ & $5(6.9)$ \\
\hline \multirow[t]{2}{*}{ Katz et al, ${ }^{9} 2007$} & Study drug: & $61(58.1)$ & $2(1.9)$ & $9(8.6)$ & I (I.0) \\
\hline & Placebo: & $44(44.0)$ & $3(3.0)$ & $8(8.0)$ & $2(2.0)$ \\
\hline \multirow[t]{2}{*}{ Vorsanger et al, ${ }^{20} 2008^{a}$} & Study drug: & $79(62.2)$ & ND & $13(10.2)$ & ND \\
\hline & Placebo: & $72(57.1)$ & ND & $18(14.3)$ & ND \\
\hline \multirow[t]{2}{*}{ Hale et al, ${ }^{21} 2010$} & Study drug: & $64(48.1)$ & I (0.8) & $7(5.3)$ & $3(2.3)$ \\
\hline & Placebo: & $73(54.9)$ & $4(3.0)$ & $3(2.3)$ & $7(5.3)$ \\
\hline \multirow[t]{2}{*}{ Katz et al, 22010} & Study drug: & $91(53.2)$ & $6(3.5)$ & $18(10.6)$ & ND \\
\hline & Placebo: & $84(48.6)$ & $3(1.7)$ & $13(7.5)$ & ND \\
\hline \multirow[t]{2}{*}{ Schwartz et al, ${ }^{23} 201 \mathrm{I}$} & Study drug: & 139 (70.9) & $10(5.1)$ & $22(11.2)$ & ND \\
\hline & Placebo: & $100(5 \mid .8)$ & $3(1.6)$ & II (5.7) & ND \\
\hline \multirow[t]{2}{*}{ Friedmann et al, ${ }^{15} 201 \mathrm{I}$} & Study drug: & ND & $5(2.4)$ & $43(21.0)$ & ND \\
\hline & Placebo: & ND & ND & ND & ND \\
\hline \multirow[t]{2}{*}{ Steiner et al, ${ }^{16} 2011$} & Study drug: & 140 (54.5) & $3(1.2)$ & $40(15.6)$ & ND \\
\hline & Placebo: & 146 (5I.6) & $2(0.7)$ & $20(7.1)$ & ND \\
\hline \multirow[t]{2}{*}{ Rauck et al, ${ }^{24} 2014$} & Study drug: & 91 (60.3) & ND & $2(1.3)$ & $0(0.0)$ \\
\hline & Placebo: & $67(44.4)$ & ND & $5(3.3)$ & $7(4.6)$ \\
\hline \multirow[t]{2}{*}{ Vinik et al, ${ }^{25} 2014$} & Study drug: & $23(13.9)$ & $8(4.8)$ & $19(11.4)$ & $4(2.4)$ \\
\hline & Placebo: & $13(8.6)$ & $9(5.9)$ & $12(7.9)$ & $5(3.3)$ \\
\hline \multirow[t]{2}{*}{ Wen et al, ${ }^{17} 2015$} & Study drug: & 136 (45.9) & $2(0.7)$ & $17(5.7)$ & ND \\
\hline & Placebo: & $103(35.3)$ & $4(1.4)$ & $10(3.4)$ & ND \\
\hline \multirow[t]{2}{*}{ Katz et al, ${ }^{18} 2015$} & Study drug: & $125(64.8)$ & $2(\mathrm{I} .0)$ & $15(7.8)$ & $3(1.6)$ \\
\hline & Placebo: & 95 (48.5) & $2(1.0)$ & $10(5.1)$ & I (0.5) \\
\hline \multirow[t]{2}{*}{ Hale et $a l,{ }^{26} 2015$} & Study drug: & $93(63.7)$ & $3(2.1)$ & $9(6.2)$ & ND \\
\hline & Placebo: & $95(48.5)$ & $2(1.0)$ & $10(5.1)$ & I (0.5) \\
\hline \multirow[t]{2}{*}{ Hale et al, ${ }^{27} 2015$} & Study drug: & $106(55)$ & $3(1.6)$ & II (5.8) & ND \\
\hline & Placebo: & $88(49)$ & $3(1.7)$ & $7(3.9)$ & ND \\
\hline \multirow[t]{2}{*}{ Rauck et al, ${ }^{28} 2016$} & Study drug: & $38(16.6)$ & $3(1.4)$ & $13(5.7)$ & $3(1.3)$ \\
\hline & Placebo: & $40(17.2)$ & I (0.5) & $7(3.0)$ & I (0.4) \\
\hline
\end{tabular}

Notes: anly data for the $300 \mathrm{mg}$ doses of tramadol were used in this meta-analysis.

Abbreviations: $A E$, adverse event; ND, no data; $S A E$, serious $A E$. 


\section{Discussion}

The recent claims that opioids lack efficacy for chronic pain have created controversy among physicians, prescribers, regulators, scientists, and the general public regarding whether the benefits of opioid use outweigh the public health risks of abuse and other complications..$^{27-30}$ Chou et al state "evidence is insufficient to determine the effectiveness of long-term opioid therapy for improving pain" based on the opinion that studies of $\leq 1$ year duration do not provide evidence of "long-term" efficacy. ${ }^{4}$ Clearly if there is no benefit then no amount of risk should be tolerated. This review was, therefore, performed in order to gather together the key evidence to facilitate understanding opioid efficacy within the paradigm of FDA studies required for approval, and to perform a meta-analysis in order to quantify opioid efficacy for chronic pain and assess consistency of effects across studies conducted for $\geq 3$ months' duration. This meta-analysis was limited to EERW-designed studies, since this design is by far the most commonly utilized for regulatory approval and therefore supports combinability.

Several systematic reviews and meta-analyses regarding the efficacy of opioids in chronic pain have been published; however, these studies were published nearly a decade $\mathrm{ago}^{4,31-33}$ and the more recent ones are not meta-analyses., ${ }^{4,34,35}$ Additionally, many studies included in previous reviews are not relevant to our study because they report alternate routes of administration (eg, intravenous), ${ }^{4}$ have short study durations, ${ }^{31,36}$ are open-label ${ }^{32,34}$ or observational studies, ${ }^{35}$ have restricted pain types, ${ }^{33,36}$ or compare different study designs. ${ }^{31,33,36}$ Although most of these meta-analyses concluded that opioids were efficacious for the treatment of chronic non-cancer pain, ${ }^{31-34,36}$ a review specifically focused on studies designed for FDA approval (ie, of $\geq 3$ months' duration) for chronic pain has not been done.

The EERW design provides an opportunity to evaluate both "effectiveness" (outcomes in the open-label titration phase) and "efficacy" (outcomes in the randomized, doubleblind, placebo-controlled phase). The present meta-analysis demonstrated the "effectiveness" of opioids since a majority of patients $(63 \%)$ demonstrated a clinically meaningful response. The pharmacological efficacy of opioids for the treatment of chronic pain was evidenced by statistically significant differences between study drug and placebo in change in pain score from randomization to week 12 and in response rates.

With regard to secondary endpoints, opioids were found to marginally improve physical function in the present metaanalysis. Therefore, the use of opioids alone to improve physical function is not supported by this review; whether opioids improve the effectiveness of rehabilitative treatments for chronic pain requires further study. Opioids did not have an appreciable positive or negative effect on mood. The PGASM measure allows subjects to aggregate multiple aspects of their experience, including pain relief, improvement in physical and emotional function, side effects, and convenience, into a single measure. ${ }^{37}$ In the present metaanalysis, these measures were congruent with the primary finding that opioids are efficacious for the treatment of chronic non-cancer pain. However, it is worth noting that the forest plot (Figure 2) showed that the efficacy estimates appear heterogeneous across studies. While the reasons for this are not certain, possible reasons include differences in study design methodology, inclusion and exclusion criteria, statistical analyses, concomitant and rescue medications, dosing, and numerous other factors.

It is worth noting that $\mathrm{AE}$ rates in the double-blind periods were similar between study drug and placebo, with dropouts due to AEs being higher in the drug group while dropouts due to loss of efficacy were higher in the placebo group. However, because patients with significant tolerability issues during the open-label titration phase are deliberately excluded from the randomized double-blind treatment phase, AE rates in the randomized double-blind treatment phase of EERW studies do not represent rates that would occur in prospective parallel clinical trials $;^{38}$ however, $\mathrm{AE}$ rates may be more reflective of ongoing $\mathrm{AE}$ rates in clinical practice, where, like in the EERW designs, patients with poor tolerability or efficacy are taken off treatment with opioids relatively early after a trial of therapy.

In a recent meta-analysis evaluating the efficacy of opioids for CLBP, the authors concluded that opioids provided "moderate short-term relief" but the effect is not clinically important. ${ }^{39}$ In that meta-analysis, Shaheed et al define "clinically important" arbitrarily as a group mean difference in pain or disability $>20$ points on a $0-100$ scale, ${ }^{39}$ while clinical importance is more usefully viewed as a multidimensional concept that encompasses multiple factors including efficacy, safety, and availability of other treatments. ${ }^{40} \mathrm{It}$ is worth noting that the efficacy of opioids is at least as large as that of any other treatment for chronic pain. ${ }^{38}$ Thus, requiring a group mean difference of 20 points on a $0-100$ pain scale would lead to a nihilistic conclusion that no pharmacological treatments for chronic pain are useful. While the effectiveness of existing treatments for chronic pain leaves plenty of room for improvement, and considering that only a small minority of patients do not experience clinically meaningful treat- 
ment responses, discarding entirely all analgesics approved for chronic pain contradicts numerous treatment guidelines, international treatment guidelines, widespread patient experience, and the FDA approval process.

These authors, as well as others, ${ }^{4}$ defined a 12 -week treatment period as "short-term." While 3 months is indeed short in comparison to the years patients may use opioid treatment for chronic pain, 3-month treatment periods are considered the regulatory standard for assessing long-term efficacy of a treatment in placebo-controlled clinical trials of chronic conditions. ${ }^{41}$ Indeed, the efficacy of all major drug and nondrug therapies for chronic pain is based on a similar body of evidence (ie, the number of studies and duration of those studies are similar for all chronic pain treatments). ${ }^{42}$ Thus, the body of evidence for the efficacy of opioids is similar in terms of duration of studies to that for other approved classes of analgesics. ${ }^{42}$

The 3-month trial duration is not entirely arbitrary: beyond several months, the internal validity of clinical trials tends to degrade due to dropouts, addition of concomitant treatments (permitted or not), noncompliance with treatment, and other factors. While it is desirable in theory to conduct prospective studies of longer duration, so that important complications that take time can emerge, and the durability of efficacy can be directly observed, the feasibility of and the technical requirements for such studies have not yet been addressed. Finally, the inclusion of EERW studies in our meta-analysis allows a richer interpretation of "long-term" efficacy: the EERW design is utilized to assess the efficacy of treatment that has been administered for potentially lengthy periods of time prior to randomization. This design, also called the randomized discontinuation design, has been used in multiple therapeutic areas where it is important to determine whether patients responding to long-term open-label treatment are, in fact, responding to the pharmacological effects of the drug, or just the non-specific effects of treatment (such as the placebo response). Such studies have been performed for decades in oncology ${ }^{43}$ depression, ${ }^{44}$ rheumatoid arthritis, ${ }^{45}$ cardiology, ${ }^{46}$ schizophrenia, ${ }^{47}$ and numerous other indications. ${ }^{48}$ Therefore, the superiority after randomization of active treatment over placebo among patients who have already demonstrated a longstanding response to open-label medication can be interpreted as long-term efficacy that is not due to a placebo effect or other non-specific factors.

Many of these products have also undergone long-term open-label extension studies to provide information on the durability of treatment responses achieved during the randomized controlled trials; we did not examine these studies in this review; however they generally demonstrate that PI reductions in patients studied in randomized controlled trials remain durable for extended periods. ${ }^{49-63}$

This meta-analysis has several limitations. First, it only included EERW studies, therefore only included results from patients who responded to opioids during the openlabel titration phase. The pros and cons of the EERW design are beyond the scope of this review, and have been amply reviewed elsewhere. ${ }^{41,64,65}$ To summarize, the advantages of the EERW study design are that it is accepted by the FDA for registration of drug treatments, ${ }^{41}$ can minimize the amount of time subjects receive ineffective or poorly tolerated treatment, may offer improved assay sensitivity, and yields open-label data that may be more relevant to clinical practice than only double-blind data. Another advantage of the EERW design is that the open-label titration phase of typical EERW studies mimics clinical practice with individual titration to optimized doses, an important design feature for medications with high inter-patient variability in optimal dose and a relatively narrow therapeutic index. ${ }^{41}$ Perceived disadvantages to the EERW design include questions about generalizability of both efficacy and AE data, challenges in comparing outcomes to standard prospective parallel treatment designs, and more complex interpretation. ${ }^{41,64,66}$ An additional limitation of note is that most of the studies included in the meta-analysis focus on CLBP, which has been a frequently used model of chronic pain because of the prevalence of the condition, and hence, the practicality of conducting clinical trials.

Many of the manuscripts screened in the present analysis failed to report critical information. This necessitated requesting data from manuscript authors, a cumbersome and timeconsuming process. We recommend that journals continue to refine and require minimum quality standards for proper interpretation and ease of use in meta-analyses. ${ }^{65}$ Initiatives like CONSORT (http://www.consort-statement.org/) and the EQUATOR network (http://www.equator-network.org/) have been put in place to foster adequate reporting of randomized controlled trials.

\section{Conclusion}

This meta-analysis of FDA-required double-blind, randomized, placebo-controlled clinical trials of opioid analgesics for the treatment of chronic pain has shown that there is an ample evidence base supporting the efficacy of opioid analgesics for at least 3 months' duration, a standard period for the evaluation of treatments for chronic pain and other chronic disorders. This evidence base is at least as large as that for any other class of analgesics, and analysis of responders 
demonstrates clinically meaningful improvements. We have not focused on the risks of opioids, nor the risk-benefit balance, and hope that our review at least characterizes the evidence base for efficacy in order to inform these important broader discussions.

\section{Acknowledgments}

The authors would like to thank Gaelen Adam for her assistance with the literature search and Bryant Smith for teaching the authors how to use several software programs that made this meta-analysis possible. The authors would also like to thank Dr. Steven Ripa, Dr. Peter Schmidt, Mary Ma, and Linda Noa for providing missing data from studies used in this meta-analysis, and Joseph Lau for his constructive review of the manuscript. This meta-analysis used methods and software tools developed by The Center for Evidence Synthesis in Health at Brown University. Support for this research was partially provided by Analgesic Solutions and partially by the Opioid Post-Marketing Requirement Consortium (OPC), an industry working group composed of pharmaceutical companies that hold an approved New Drug Application for extended release/long-acting opioids working together at FDA's request to conduct certain post-market required studies. The OPC includes Allergan, Plc, BioDelivery Systems International, Inc., Collegium Pharmaceuticals, Inc., Daiichi Sankyo, Inc., Depomed, Inc., Egalet Corporation, Endo Pharmaceuticals Inc., Janssen Pharmaceuticals Inc., Mallinckrodt, Inc., Pernix Therapeutics Holdings, Inc., Pfizer Inc., Purdue Pharma, L. P., and West-Ward Pharmaceuticals Corp. Current affiliation for Diana S Meske is Collegium Pharmaceutical Inc, Canton, MA, USA.

\section{Disclosure}

Nathaniel Katz has acted as a consultant for Allergan, Plc, Collegium Pharmaceuticals, Inc., Depomed, Inc., Egalet Corporation, Endo Pharmaceuticals Inc., Janssen Pharmaceuticals, Inc., Mallinckrodt, Inc., Pfizer Inc., and Purdue Pharma, L. P. Diana S Meske was employed by Analagesic Solutions when the work was completed for this manuscript, however at the time of publication she was employed by Collegium Pharmaceutical Inc. The authors report no other conflicts of interest in this work.

\section{References}

1. The use of opioids for the treatment of chronic pain: A consensus statement from the American Academy of Pain Medicine and the American Pain Society [press release]. Glenview, IL, USA; 1997.
2. The use of opioids for the treatment of chronic pain: a consensus statement from the American Academy of Pain Medicine and the American Pain Society [press release]. Dallas, TX, USA; 1998.

3. US Centers for Disease Control and Prevention (CDC). CDC Guideline for Prescribing Opioids for Chronic Pain. In:2016.

4. Chou R, Turner JA, Devine EB, et al. The effectiveness and risks of long-term opioid therapy for chronic pain: a systematic review for a national institutes of health pathways to prevention workshop. Ann Intern Med. 2015;162(4):276-286.

5. Frieden TR, Houry D. Reducing the risks of relief - The CDC opioidprescribing guideline. $N$ Engl J Med. 2016;374(16):1501-1504.

6. Ballantyne JC. Opioid therapy in chronic pain. Phys Med Rehabil Clin NAm. 2015;26(2):201-218.

7. Birnbaum HG, White AG, Schiller M, Waldman T, Cleveland JM, Roland CL. Societal costs of prescription opioid abuse, dependence, and misuse in the United States. Pain Med. 2011;12(4):657-667.

8. Substance Abuse and Mental Health Services Administration. Behavioral health trends in the United States: results from the 2014 national survey on drug use and health. Rockville, MD: SAMHSA; 2015. Available from: https:/www.samhsa.gov/data/sites/default/files/NSDUHFRR1-2014/NSDUH-FRR1-2014.pdf. Accessed April 16, 2018.

9. Katz NP, Adams EH, Benneyan JC, et al. Foundations of opioid risk management. Clin J Pain. 2007;23(2):103-118.

10. Paulozzi LJ, Weisler RH, Patkar AA. A national epidemic of unintentional prescription opioid overdose deaths: how physicians can help control it. J Clin Psychiatry. 2011;72(5):589-592.

11. Wallace BC, Small K, Brodley CE, Lau J, Trikalinos TA. Deploying an interactive machine learning system in an evidence-based practice center: abstrackr. Proceedings of the 2nd ACM SIGHIT International Health Informatics Symposium, Miami, FL, 28-30 January 2012. New York, NY: ACM; 2012:819-824.

12. Johnston BC, Patrick DL, Busse JW, Schunemann HJ, Agarwal A, Guyatt GH. Patient-reported outcomes in meta-analyses - Part 1: assessing risk of bias and combining outcomes. Health Qual Life Outcomes. 2013;11:109.

13. Wallace BC, Dahabreh IJ, Trikalinos TA, Lau J, Trow P, Schmid CH. Closing the gap between methodologists and end-users: R as a computational back-end. J Stat Software. 2012;49(5):4700.

14. Hale M, Tudor IC, Khanna S, Thipphawong J. Efficacy and tolerability of once-daily OROS hydromorphone and twice-daily extended-release oxycodone in patients with chronic, moderate to severe osteoarthritis pain: results of a 6-week, randomized, open-label, noninferiority analysis. Clin Ther. 2007;29(5):874-888.

15. Friedmann N, Klutzaritz V, Webster L. Efficacy and safety of an extendedrelease oxycodone (Remoxy) formulation in patients with moderate to severe osteoarthritic pain. J Opioid Manag. 2011;7(3):193-202.

16. Steiner D, Munera C, Hale M, Ripa S, Landau C. Efficacy and safety of buprenorphine transdermal system (BTDS) for chronic moderate to severe low back pain: a randomized, double-blind study. J Pain. 2011;12(11):1163-1173.

17. Wen W, Sitar S, Kynch S, He E, Ripa SR. A multicenter, randomized, double-blind, placebo-controlled trial to assess the efficacy and safety of single-entity, once-daily hydrocodone tablets in patients with uncontrolled moderate to severe chronic low back pain. Expert Opin Pharmacother. 2015;16(11):1593-1606.

18. Katz N, Kopecky EA, O'Connor M, Brown RH, Fleming AB. A phase 3, multicenter, randomized, double-blind, placebo-controlled, safety, tolerability, and efficacy study of Xtampza ER in patients with moderateto-severe chronic low back pain. Pain. 2015;156(12):2458-2467.

19. Katz N, Rauck R, Ahdieh H, et al. A 12-week, randomized, placebocontrolled trial assessing the safety and efficacy of oxymorphone extended release for opioid-naive patients with chronic low back pain. Curr Med Res Opin. 2007;23(1):117-128.

20. Vorsanger GJ, Xiang J, Gana TJ, Pascual ML, Fleming RR. Extendedrelease tramadol (tramadol ER) in the treatment of chronic low back pain. J Opioid Manag. 2008;4(2):87-97. 
21. Hale M, Khan A, Kutch M, Li S. Once-daily OROS hydromorphone ER compared with placebo in opioid-tolerant patients with chronic low back pain. Curr Med Res Opin. 2010;26(6):1505-1518.

22. Katz N, Hale M, Morris D, Stauffer J. Morphine sulfate and naltrexone hydrochloride extended release capsules in patients with chronic osteoarthritis pain. Postgrad Med. 2010;122(4):112-128.

23. Schwartz S, Ertopolski M, Shapiro DY, et al. Safety and efficacy of tapentadol ER in patients with painful diabetic peripheral neuropathy: results of a randomized-withdrawal, placebo-controlled trial. Curr Med Res Opin. 2011;27(1):151-162.

24. Rauck RL, Nalamachu S, Wild JE, et al. Single-entity hydrocodone extended-release capsules in opioid-tolerant subjects with moderateto-severe chronic low back pain: a randomized double-blind, placebocontrolled study. Pain Med. 2014;15(6):975-985.

25. Vinik AI, Shapiro DY, Rauschkolb C. A randomized withdrawal, placebo-controlled study evaluating the efficacy and tolerability of tapentadol extended release in patients with chronic painful diabetic peripheral neuropathy. Diabetes Care. 2014;37(8):2302-2309.

26. Hale ME, Laudadio C, Yang R, Narayana A, Malamut R. Efficacy and tolerability of a hydrocodone extended-release tablet formulated with abusedeterrence technology for the treatment of moderate-to-severe chronic pain in patients with osteoarthritis or low back pain. J Pain Res. 2015;8:623-636.

27. Hale ME, Zimmerman TR, Eyal E, Malamut R. Efficacy and safety of a hydrocodone extended-release tablet formulation with abuse-deterrence technology in patients with moderate-to-severe chronic low back pain. J Opioid Manag. 2015;11(6):507-518.

28. Rauck RL, Potts J, Xiang Q, Tzanis E, Finn A. Efficacy and tolerability of buccal buprenorphine in opioid-naive patients with moderate to severe chronic low back pain. Postgrad Med. 2016;128(1):1-11.

29. Furlan AD, Sandoval JA, Mailis-Gagnon A, Tunks E. Opioids for chronic noncancer pain: a meta-analysis of effectiveness and side effects. CMAJ. 2006;174(11):1589-1594.

30. Noble M, Tregear SJ, Treadwell JR, Schoelles K. Long-term opioid therapy for chronic noncancer pain: a systematic review and meta-analysis of efficacy and safety. J Pain Symptom Manage. 2008;35(2):214-228.

31. Deshpande A, Furlan A, Mailis-Gagnon A, Atlas S, Turk D. Opioids for chronic low-back pain. Cochrane Database Syst Rev. 2007;3:CD004959.

32. Kalso E, Edwards JE, Moore RA, McQuay HJ. Opioids in chronic non-cancer pain: systematic review of the efficacy and safety. Pain 2004;112(3):372-380.

33. Hauser W, Bernardy K, Maier C. [Long-term opioid therapy in chronic noncancer pain: a systematic review and meta-analysis of efficacy, tolerability, and safety in open-label extension trials with study duration of at least 26 weeks]. Schmerz. 2015;29(1):96-108. German.

34. Chaparro LE, Furlan AD, Deshpande A, Mallis-Gagnon A, Atlas S, Turk DC. Opioids compared with placebo or other treatments for chronic low back pain: an update of the cochrane review. Spine (Phila Pa 1976). 2014;39(7):556-563.

35. Dworkin RH, Turk DC, Farrar JT, et al; IMMPACT. Core outcome measures for chronic pain clinical trials: IMMPACT recommendations. Pain. 2005;113(1-2):9-19.

36. Abdel Shaheed C, Maher CG, Williams KA, Day R, McLachlan AJ. Efficacy, tolerability, and dose-dependent effects of opioid analgesics for low back pain: a systematic review and meta-analysis. JAMA Intern Med. 2016;176(7):958-968.

37. Katz NP, Paillard FC, Ekman E. Determining the clinical importance of treatment benefits for interventions for painful orthopedic conditions. J Orthop Surg Res. 2015;10:24.

38. Katz N, Benoit C. Opioids for neuropathic pain. Curr Pain Headache Rep. 2005;9:153-160.

39. US Food and Drug and Administration (FDA), Center for Drug Evaluation and Research (CDER). Guidance for industry analgesic indications: developing drug biological products. Rockville, MD: FDA, CDER; 2014. Available from: http://www.fda.gov/downloads/Drugs/ GuidanceComplianceRegulatoryInformation/Guidances/UCM384691. pdf. Accessed April 16, 2018.
40. Dworkin RH, Turk DC, Peirce-Sandner S, et al. Considerations for improving assay sensitivity in chronic pain clinical trials: IMMPACT recommendations. Pain. 2012;153(6):1148-1158.

41. Katz N. Enriched enrollment randomized withdrawal trial designs of analgesics: a focus on methodology. Clin J Pain. 2009;25(9): 797-807.

42. Tayeb BO, Barreiro AE, Bradshaw YS, Chui KK, Carr DB. Durations of opioid, nonopioid drug, and behavioral clinical trials for chronic pain: adequate or inadequate? Pain Med. 2016;17(11):2036-2046.

43. Wakelee HA, Lee JW, Hanna NH, Traynor AM, Carbone DP, Schiller JH. A double-blind randomized discontinuation phase-II study of sorafenib (BAY 43-9006) in previously treated non-small-cell lung cancer patients: eastern cooperative oncology group study E2501. J Thorac Oncol. 2012;7(10):1574-1582.

44. Vohringer PA, Ostacher MJ, El-Mallakh RS, et al. Antidepressants in type II versus type I bipolar depression: a randomized discontinuation trial. J Clin Psychopharmacol. 2015;35(5):605-608.

45. Kemper AR, Van Mater HA, Coeytaux RR, Williams JW, Sanders GD. Systematic review of disease-modifying antirheumatic drugs for juvenile idiopathic arthritis. BMC Pediatr. 2012;15:29.

46. Ponten J, Biber B, Bjurij T, Henriksson B, Hjalmarson A, Lundberg D. Beta-receptor blockade and spinal anaesthesia withdrawal versus continuation of long-24 term therapy. Acta Anaesth Scand. 1982;76(1): $62-69$.

47. McCreadie R, Wiles D, Grant S, et al. The Scottish first episode schizophrenia study. VII. Two-year follow-up. Scottish Schizophrenia Research Group. Acta Psychiatr Scand. 1989;80(6):597-602.

48. Kopec JA, Abrahamowicz M, Esdaile JM. Randomized discontinuation trials: utility and efficiency. J Clin Epidemiol. 1993;46(9):959-971.

49. Buynak R, Rappaport SA, Rod K, et al. Long-term safety and efficacy of tapentadol extended release following up to 2 years of treatment in patients with moderate to severe, chronic pain: results from an openlabel extension trial. Clin Ther. 2015;37(11):2420-2438.

50. Hale M, Urdaneta V, Kirby MT, Xiang Q, Rauck R. Long-term safety and analgesic efficacy of buprenorphine buccal film in patients with moderate-to-severe chronic pain requiring around-the-clock opioids. J Pain Res. 2017;10:233-240.

51. Hale ME, Ma Y, Malamut R. Six-month, open-label study of hydrocodone extended release formulated with abuse-deterrence technology: safety, maintenance of analgesia, and abuse potential. J Opioid Manag. 2016;12(2):139-147.

52. Taber L, Lynch SY, He E, Ripa SR. Long-term safety and effectiveness of once-daily, single entity, extended-release hydrocodone over 76 weeks of an open-label study in patients with chronic noncancer and nonneuropathic pain. Postgrad Med. 2016;128(1):23-33.

53. Hale ME, Zimmerman TR, Ma Y, Malamut R. Twelve-month, open-label assessment of long-term safety and abuse potential of hydrocodone extended-release formulated with abuse-deterrence technology in patients with chronic pain. J Opioid Manag. 2015;11(5):425-434.

54. Wen W, Taber L, Lynch SY, He E, Ripa S. 12-month safety and effectiveness of once-daily hydrocodone tablets formulated with abuse-deterrent properties in patients with moderate to severe chronic pain. J Opioid Manag. 2015;11(4):339-356.

55. Arora S, Setnik B, Michael D, et al. A multicenter, 12-month, openlabel, single-arm safety study of oxycodone-hydrochloride/naltrexone-hydrochloride extended-release capsules (ALO-02) in patients with moderate-to-severe chronic noncancer pain. J Opioid Manag. 2014;10(6):423-436.

56. Nalamachu S, Rauck RL, Hale ME, Florete OG, Robinson CY, Farr SJ. A long-term, open-label safety study of single-entity hydrocodone bitartrate extended release for the treatment of moderate to severe chronic pain. J Pain Res. 2014;7:669-678.

57. Friedmann N, Klutzaritz V, Webster L. Long-term safety of Remoxy ${ }^{\mathbb{R}}$ (extended-release oxycodone) in patients with moderate to severe chronic osteoarthritis or low back pain. Pain Med. 2011;12(5): $755-760$. 
58. Wallace M, Thipphawong J. Open-label study on the long-term efficacy, safety, and impact on quality of life of OROS hydromorphone ER in patients with chronic low back pain. Pain Med. 2010;11(10): 1477-1488.

59. Webster LR, Brewer R, Wang C, et al. Long-term safety and efficacy of morphine sulfate and naltrexone hydrochloride extended release capsules, a novel formulation containing morphine and sequestered naltrexone, in patients with chronic, moderate to severe pain. $J$ Pain Symptom Manage. 2010;40(5):734-746.

60. Wild JE, Grond S, Kuperwasser B, et al. Long-term safety and tolerability of tapentadol extended release for the management of chronic low back pain or osteoarthritis pain. Pain Pract. 2010;10(5):416-427.

61. Wallace M, Moulin DE, Rauck RL, et al. Long-term safety, tolerability, and efficacy of OROS hydromorphone in patients with chronic pain. J Opioid Manag. 2009;5(2):97-105.

62. Pascual ML, Fleming RR, Gana TJ, Vorsanger GJ. Open-label study of the safety and effectiveness of long-term therapy with extended-release tramadol in the management of chronic nonmaligant pain. Curr Med Res Opin. 2007;23(10):2531-2542.
63. McIlwain H, Ahdieh H. Safety, tolerability, and effectiveness of oxymorphone extended release for moderate to severe osteoarthritis pain: a one-year study. Am J Ther. 2005;12(2):106-112.

64. Moore A, Wiffen PJ, Eccleston C, et al. Systematic review of enrichedenrollment randomized-withdrawal trial designs in chronic pain: a new framework for design and reporting. Pain. 2015;156(8):1382-1395.

65. US Department of Health and Human Services (DHHS), Food and Drug Administration (FDA), Center for Drug Evaluation and Research (CDER), Center for Biologics Evaluation and Research (CBER), Center for Devices and Radiological Health (CDRH). Guidance for Industry: Enrichment Strategies for Clinical Trials to Support Approval of Human Drugs and Biological Products. Rockville, MD: DHHS, FDA, CDER, CBER, CDRH; 2012. Available from: https://www.fda.gov/downloads/drugs/guidancecomplianceregulatoryinformation/guidances/ ucm332181.pdf. Accessed April 16, 2018.

66. Furlan A, Chaparro LE, Irvin E, Mailis-Gagnon A. A comparison between enriched and nonenriched enrollment randomized withdrawal trials of opioids for chronic noncancer pain. Pain Res Manag. 2011;16(5):337-351.
Journal of Pain Research

\section{Publish your work in this journal}

The Journal of Pain Research is an international, peer reviewed, open access, online journal that welcomes laboratory and clinical findings in the fields of pain research and the prevention and management of pain. Original research, reviews, symposium reports, hypothesis formation and commentaries are all considered for publication.

\section{Dovepress}

The manuscript management system is completely online and includes a very quick and fair peer-review system, which is all easy to use. Visit http://www.dovepress.com/testimonials.php to read real quotes from published authors. 